\title{
Synergistic effect of stromelysin-1 (matrix metalloproteinase-3) promoter (-1171 5A->6A) polymorphism in oral submucous fibrosis and head and neck lesions
}

Ajay K Chaudhary ${ }^{1,2}$, Mamta Singh ${ }^{2}$, Alok C Bharti ${ }^{3}$, Mangal Singh ${ }^{4}$, Shirish Shukla ${ }^{3}$, Atul K Singh $^{5}$, Ravi Mehrotra ${ }^{2^{*}}$

\begin{abstract}
Background: Matrix metalloproteinases (MMPs) are enzymes that degrade all the components of extra cellular matrix and collagen. Various types of MMPs are known to be expressed and activated in patients with oral submucous fibrosis (OSMF) as well as head and neck squamous cell carcinoma (HNSCC). The purpose of this study was to asses the association of the single nucleotide polymorphism (SNP) adenosine insertion/deletion polymorphism (-1171 5A->6A) in the MMP-3 promoter region in these lesions.
\end{abstract}

Methods: MMP-3 SNP was genotyped by polymerase chain reaction-restriction fragment polymorphism (PCR-RFLP) analysis in a case control study consisting of 362 participants; 101 cases of OSMF, 135 of HNSCC and 126 controls, compared for age, sex and habits. ROC distribution was plotted to assess the contributions of genetic variation in MMP-3 genotypes with relation to age.

Results: Analysis of MMP 3 (-1171 5A->6A) polymorphism revealed the frequency of $5 \mathrm{~A}$ allele in OSMF, HNSCC and controls to be $0.15,0.13$ and 0.07 , respectively. A significant difference was found in $5 \mathrm{~A}$ genotype frequency between OSMF (5A genotype frequency $=0.15, \mathrm{p}=0.01, \mathrm{OR}=2.26,95 \% \mathrm{Cl}=1.22-4.20$ ) and in controls (5A genotype frequency 0.07 ) as well as HNSCC ( $5 \mathrm{~A}$ genotype frequency $0.13, \mathrm{p}=0.03,95 \% \mathrm{Cl}=1.06-3.51$ ) and controls $(5 \mathrm{~A}$ genotype frequency $=0.07$ ) In this study, 5A genotype had greater than two fold risk for developing OSMF $(\mathrm{OR}=2.26)$ and nearly the same in case of HNSCC $(\mathrm{OR}=1.94)$ as compared to controls. In patients with OSMF as well as HNSCC, the ROC analysis between the MMP-3 genotype and age, 6A/6A allele was found to be significant in patients both over and under 45 years of age; while the $5 \mathrm{~A} / 5 \mathrm{~A}$ carrier alleles showed an association only in patients less than 45 years of age.

Conclusions: This study concluded that the expression of MMP-3 genotype associated with the 5A alleles, it may have an important role in the susceptibility of the patients to develop OSMF and HNSCC.

\section{Background}

Matrix metalloproteinases (MMP) are a group of structurally related zinc-dependent endopeptidases and have the capability to degrade all components of extra cellular matrix (ECM) [1]. MMPs are synthesized mainly by fibroblasts and to a lesser extent by activated macrophages and keratinocytes adjacent to the sites of injury [2]. MMP-3, also known as stromelysin-1, it is responsible for

\footnotetext{
* Correspondence: rm8509@gmail.com

${ }^{2}$ Department of Pathology, Moti Lal Nehru Medical College, Allahabad, 211002 India
}

degradation of collagen type IV [3]. Brinckerhoff et al reported that MMP-3 also plays an important role in activation of proMMP-1 into the active form of MMP-1 in malignant tissues [4]. MMP-3 expression is low in normal tissues but it is altered during tumour formation, where remodeling of the extra cellular matrix is required [5]. MMP-3 has wide substrate specificity for various ECM components and is involved in many biological functions, including extracellular matrix degradation and remodelling, cell proliferation, angiogenesis as well as induction of synthesis of other metalloproteinases such as MMP-1 and
C Biomed Central

() 2010 Chaudhary et al; licensee BioMed Central Ltd. This is an Open Access article distributed under the terms of the Creative Commons Attribution License (http://creativecommons.org/licenses/by/2.0), which permits unrestricted use, distribution, and reproduction in any medium, provided the original work is properly cited. 
MMP-9 [6]. The author's group recently reviewed the molecular functions and single nucleotide polymorphic association of different MMPs such as MMP-1 (-1607 1G/ 2G), MMP-2 (-1306 C/T), MMP-3 (-1171 5A/6A), MMP$9(-1562 \mathrm{C} / \mathrm{T})$ and TIMP-2 $(-418 \mathrm{G} / \mathrm{C}$ or $\mathrm{C} / \mathrm{C})$ and it's possible therapeutic aspects of these proteases and they concluded that MMPs may play an association with potentially malignant (OSMF) and malignant head and neck lesions (HNSCC). Further research is required for the development of their potential diagnostic and therapeutic possibilities [7].

The expression of MMP-3 in carcinogenesis is regulated primarily at the transcriptional level, but there is also evidence of modulation of mRNA stability in response to growth factors and cytokines secreted by tumour-infiltrating inflammatory cells as well as by tumour and stromal cells [3,5,8]. MMP-3 transcription is higher in head and neck squamous cell carcinoma (HNSCC) and several other types of malignancies including lung and breast carcinomas [9-12]. MMP-3 degrades types II, V, IX and X collagens, proteoglycans, gelatine, fibronectin, laminin and elastin [13]. MMP-3 can also activate other MMPs, including collagenase, matrilysin and gelatinase $\mathrm{B}$.

The MMP-3 gene has been mapped to the long arm of chromosome 11q22.3 and the level of expression of this gene can be influenced by single nucleotide polymorphisms (SNPs) in the promoter region of their respective gene [14]. The promoter region of MMP3 is characterized by a $5 \mathrm{~A} / 6 \mathrm{~A}$ promoter polymorphism at position -1171 in which one allele has six adenosine (6A) and the second has five adenosine (5A). A single adenosine insertion/deletion polymorphism (5A/6A) at position -1171 of the MMP-3 promoter region causes different transcription of MMP-3.

In-vitro assays of promoter activity showed that the $5 \mathrm{~A}$ allele had a two-fold higher promoter activity than the $6 \mathrm{~A}$ allele [15]. The $5 \mathrm{~A}$ allele is more prevalent in the European population (frequency range $40-50 \%$ ) as compared to East Asian population (frequency range 7$20 \%)[11,14,16]$. At position -1171 of the promoter region of the MMP-3 gene, a polymorphism of 5 or 6 adenosines (5A/6A) affects its low transcription level. The $5 \mathrm{~A}$ allele results in higher gene expression in fibroblasts and vascular smooth muscle cells compared to the $6 \mathrm{~A}$ allele and the $6 \mathrm{~A}$ allele has a lower promoter reactivity than the $5 \mathrm{~A}$ allele in vitro [14].

The aim of this study was to find out the association of the $-11715 \mathrm{~A}->6 \mathrm{~A}$ polymorphism in the MMP-3 gene in patients suffering from OSMF, HNSCC and healthy controls.

\section{Methods}

Patients with OSMF and HNSCC as well as controls from the Departments of Otorhinolaryngology and
Pathology, Moti Lal Nehru Medical College, Allahabad, India, were included in the study from June 2007 to October 2009; this study was approved by the institutional ethical committee. This case-control study group included 362 participants. Two hundred and thirty six subjects (average age $43.4 \pm 14.8$ years) were included in this study, of which 101 patients suffered from OSMF (78 males and 23 females) and 135 patients from HNSCC (114 males and 21 females) and 126 healthy subjects who did not have a history of pre-malignant or malignant lesions. These (average age $37.01 \pm 12.89$ years, 105 males 21 females) healthy controls were compared for age, sex and habits. Detailed clinical and personal information of each patient was noted in a standardized proforma. Information regarding the patients name, age, sex, occupation, personal habits and present complaints was gathered. Emphasis was given to addictions like areca nut, tobacco and alcohol. None of the HNSCC patients gave a history of having OSMF prior to developing malignancy. Individuals with haematological diseases, previous malignancies, skin diseases and autoimmune disorders were excluded from the study. All cases were histopathologically confirmed. The blood samples were taken after obtaining the patients informed consent to participate in the study. $5 \mathrm{ml}$. blood was drawn from each subject into vacutainer tubes containing ethylene-di-amine-tetra-acetic acid (EDTA) and stored at $4^{\circ} \mathrm{C}$ till the samples were processed and isolation of genomic DNA was done.

\section{Isolation of Genomic DNA}

Genomic DNA was extracted from the blood samples by using the Qiagen QIAamp DNA Blood Mini Kit (Qiagen Inc. USA) The extracted genomic DNA was quantified and checked for purity by spectrophotometer (Spectro UV-Vis Double Beam PC, UVD Model 2950 LABOMED, Inc. CA, USA). Ethidium bromide (EtBr) stained $0.8 \%$ agarose gel electrophoresis was used to confirm the presence of genomic DNA in patient and controls samples.

\section{Genotyping of the MMP-3 promoter polymorphism}

The MMP-3 genotype was determined by the PCRRFLP assay. The PCR primers used for amplifying the MMP-3 polymorphism were: forward primer (FP) 5'GGTTCTCCATTCCTTTGATGGGGGGAAAGA-3' and reverse primer (RP) 5'-CTTCCTGGAATTCACATCACTGCCACCACT-3' [17]. An A to G mutation at the second nucleotide close to the 3' end of the FP was made to create a Tth111I (TakaRa Biotechnology Co. Ltd, Dalian, China) recognition site in the case of a $5 \mathrm{~A}$ allele. PCR (MJ Research PTC 100, GMI, Inc, Minnesota, USA) was performed in a $25 \mu$ l volume containing $50 \mathrm{ng}$ of genomic DNA template, $2.5 \mu \mathrm{l}$ of $10 \times$ PCR 
buffer, $2.5 \mathrm{mmol}$ of $\mathrm{MgCl}_{2}, 1 \mathrm{U}$ of Taq DNA polymerase (Fermentas Inc. Glen Burnie MD), $200 \mathrm{nmol}$ of dNTPs and $200 \mathrm{nmol}$ of forward and reverse primer. The PCR cycling conditions were $5 \mathrm{~min}$ at $94^{\circ} \mathrm{C}$ followed by 35 cycles of $45 \mathrm{~s}$ at $94^{\circ} \mathrm{C}, 45 \mathrm{~s}$ at $66^{\circ} \mathrm{C}$ and $45 \mathrm{~s}$ at $72^{\circ} \mathrm{C}$ and with a final step at $72^{\circ} \mathrm{C}$ for $15 \mathrm{~min}$ to allow for the complete extension of all PCR fragments. For a negative control, each PCR reaction used distilled water instead of DNA in the reaction mixture.

\section{Restriction enzyme (Tth 111I) digestion of MMP-3 gene}

A $10 \mu \mathrm{l}$ aliquot of PCR product was digested at $65^{\circ} \mathrm{C}$ for $5 \mathrm{hrs}$ in a $15 \mu \mathrm{l}$ reaction containing $10 \mathrm{U}$ of Tth111 I and $1 \times$ reaction buffer. After digestion, the products were separated on 3.5\% agarose gel stained with EtBr. On electrophoresis, the $5 \mathrm{~A}$ alleles were represented by DNA bands of 97 and $32 \mathrm{bp}$, the 6A alleles were represented by a DNA band of $129 \mathrm{bp}$, whereas the heterozygote displayed a combination of both alleles (129, 97 and $32 \mathrm{bp})$ Fig. 1[A] and 1[B].

\section{Statistical analysis}

The Chi-square test $\left(\chi^{2}\right.$ test) was used to find out the difference in genotypic distribution of MMP-3 promoters between the OSMF, HNSCC and control groups. Fisher's exact test has also been applied in the statistical analysis. A p-value of $<0.05$ was considered as statistically significant. For each parameter, patients with OSMF histopathological grade I, II, III, IV and HNSCC, risk was analyzed by odds ratios (OR) and 95\% Confidence Intervals $(95 \% \mathrm{CI})$. Distributions of MMP-3 genotype promoter polymorphisms in OSMF, HNSCC and control groups were analyzed by the Hardy-Weinberg equilibrium. The statistical analysis was performed using the SPSS 15.0 software package (SPSS Japan Inc., Tokyo, Japan).

\section{Results}

Patients of OSMF were diagnosed on the basis of clinical signs including trismus and presence of fibrotic bands in the oral cavity and malignancies. Figure 2[A, B, $\mathrm{C}]$ and 2[D]. MMP-3 promoter genotypes in patients with OSMF, HNSCC and controls were analyzed with respect to gender, age, habits like tobacco consumption with or without areca nut chewing, alcohol intake, as well as histopathological grade of OSMF, TNM staging of HNSCC and the location of the lesion.

Out of 101 patients with OSMF, 74 (73.27\%) had 6A/ 6A genotype, 24 (23.76\%) 5A/6A and 3 (2.97\%) 5A/5A, while in 135 patients with HNSCC, 106 (78.5\%) had 6A/ 6A genotype, 23 (17.03\%) 5A/6A and 6 (4.44\%) 5A/5A. Of the male patients with OSMF, 62 had $6 \mathrm{~A} / 6 \mathrm{~A}, 14$ $(5 \mathrm{~A} / 6 \mathrm{~A})$ and $2(5 \mathrm{~A} / 5 \mathrm{~A})$ genotype and of the female patients, 12 had $6 \mathrm{~A} / 6 \mathrm{~A}, 10(5 \mathrm{~A} / 6 \mathrm{~A})$ and $1(5 \mathrm{~A} / 5 \mathrm{~A})$
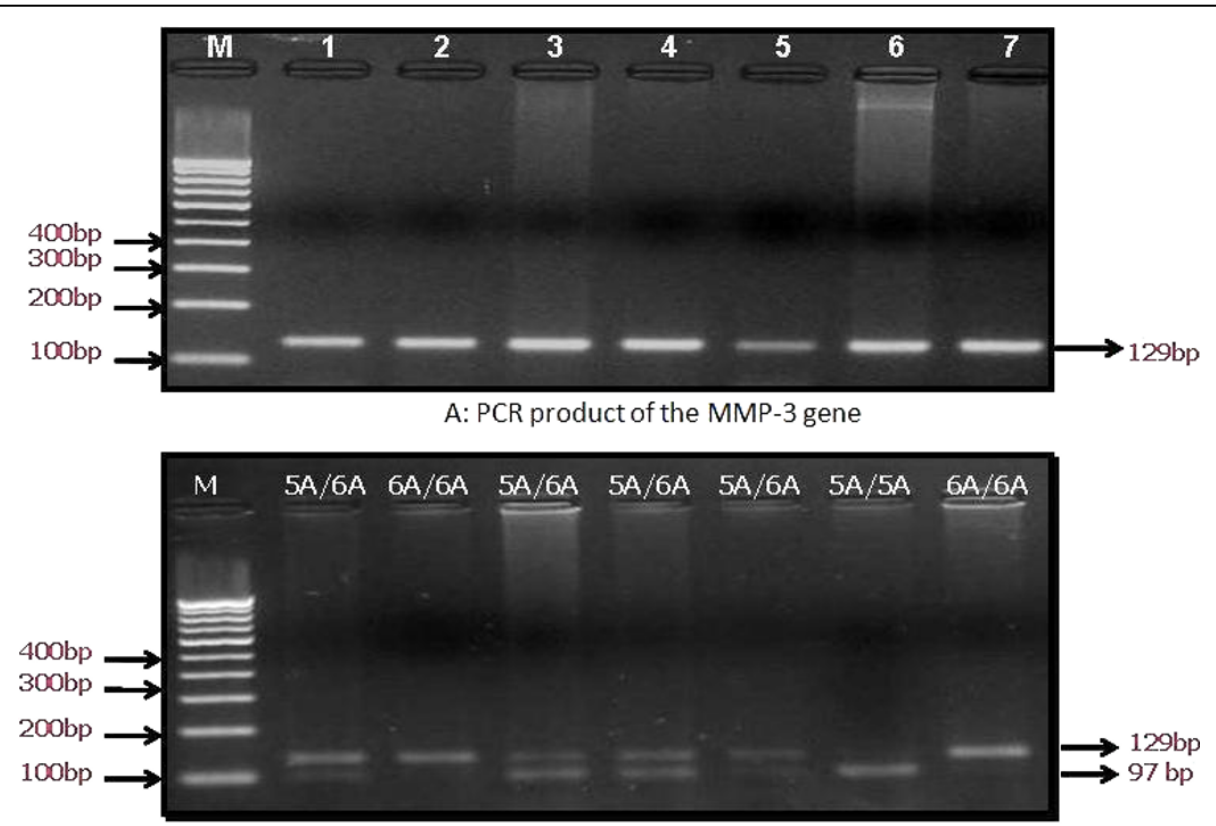

B: PCR -RFLP product of the MMP-3 gene

Figure 1 A The expected PCR product size of MMP-3 gene by 100 bp marker [M], Lane 1-7 shows PCR product followed by separation on 2.0\% agarose gel was confirmed; B: Genotyping of MMP-3 Promoter (-1171 5A->6A) Polymorphism by PCR-RFLP analysis followed by separation on $3.5 \%$ agarose gel, Lane $M=100$ bp marker; lane $1,3,4,5=5 A / 6 A$; lane $2=5 A / 6 A$; lane $6=5 A / 5 A$. 


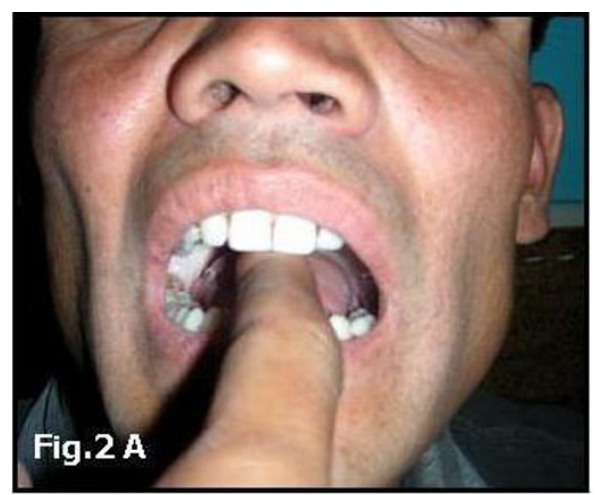

A: Patients with OSMF showing trismus (mouth opening 1 finger)

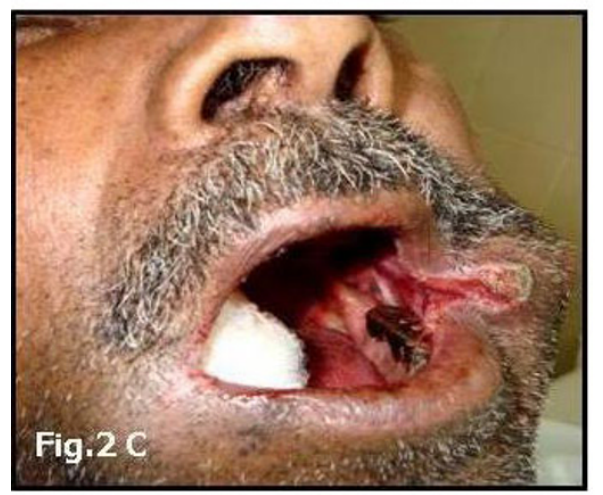

C: Malignancy of buccal mucosa

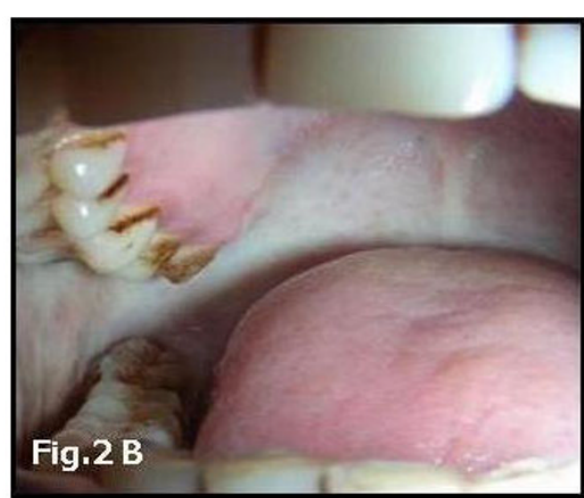

B: Blanching and fibrosis in OSMF

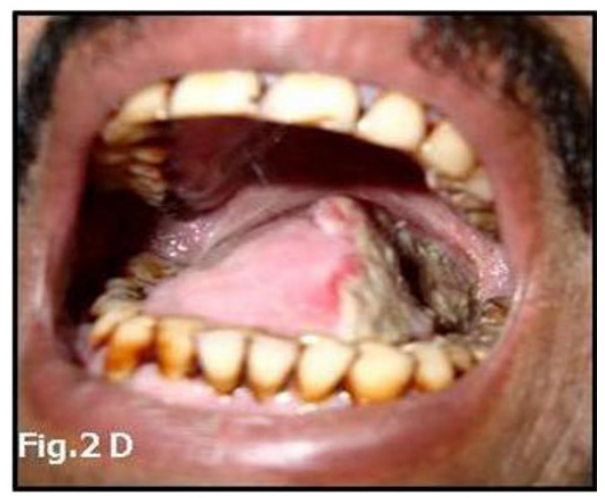

D: Tongue malignancy

Figure 2 Clinical picture of patients with OSMF and HNSCC.

genotype. In male patients with HNSCC, 94 had $6 \mathrm{~A} / 6 \mathrm{~A}$, $15(5 \mathrm{~A} / 6 \mathrm{~A})$ and $5(5 \mathrm{~A} / 5 \mathrm{~A})$ genotype and of the females, 12 had $6 \mathrm{~A} / 6 \mathrm{~A}, 8(5 \mathrm{~A} / 6 \mathrm{~A})$ and $1(5 \mathrm{~A} / 5 \mathrm{~A})$ genotype. Analyzing the different genotypes $(6 \mathrm{~A} / 6 \mathrm{~A}, 5 \mathrm{~A} / 6 \mathrm{~A}$ and $5 \mathrm{~A} /$ $5 \mathrm{~A}$ ), it was found that the polymorphic association of these genotypes was statistically significant in both male and females suffering from OSMF $(\mathrm{p}=0.001)$ and HNSCC $(\mathrm{p}=0.01)$, according to the Fisher's exact test. This conclusion was drawn on analysis of the dataset illustrated in Table no 1.

Association of $5 \mathrm{~A} / 5 \mathrm{~A}, 6 \mathrm{~A} / 6 \mathrm{~A}$ and $5 \mathrm{~A} / 6 \mathrm{~A}$ genotypes and tobacco chewing with areca nut chewers showed a significant association in OSMF and HNSCC cases respectively $(\mathrm{p}=0.02,0.003)$ as did the $\operatorname{OSMF}(\mathrm{p}=$ $0.001)$ and HNSCC histopathological grading ( $\mathrm{p}=$ $0.001)$ as well as location, both in OSMF and HNSCC ( $\mathrm{p}=0.81$ and $\mathrm{p}=0.59$ respectively) [Table 1 ].

The MMP-3 genotype distinguished homozygous $6 \mathrm{~A}$ genotype (6A/6A), homozygous $5 \mathrm{~A}$ genotype (5A/5A) and heterozygous genotype (5A/6A). The $5 \mathrm{~A}$ allele frequencies in OSMF, HNSCC and controls were $0.15,0.13$ and 0.07 respectively (According to Hardy-Weinberg equilibrium). A significant difference was found in $5 \mathrm{~A}$ allele frequency between OSMF and controls $(\mathrm{p}=0.01)$, as well as HNSCC and controls $(\mathrm{p}=0.03)$. 5A genotype had a more than two fold risk for OSMF $(\mathrm{OR}=2.26)$ and little less in HNSCC $(\mathrm{OR}=1.94)$ in relation to the control group. Frequency of $5 \mathrm{~A} / 6 \mathrm{~A}$ or $5 \mathrm{~A} / 5 \mathrm{~A}$ promoter genotypes having $5 \mathrm{~A}$ alleles was associated with MMP-3 single nucleotide polymorphism (SNP) in OSMF (5A allele frequency $=0.15, \mathrm{p}=0.01, \mathrm{OR}=2.26,95 \% \mathrm{CI}=$ 1.22-4.20). Similar difference was also found in MMP-3 genotype distribution in HNSCC (5A allele frequency = $0.13, \mathrm{p}=0.03, \mathrm{OR}=1.94,95 \% \mathrm{CI} 1.06-3.51)$ as compared to controls (5A allele frequency $=0.07$ ) [Table 2].

Receiver operating characteristics (ROC) showed a significant association between age and MMP-3 genotypes in OSMF and HNSCC. Figure $3[\mathrm{~A}]$ and $3[\mathrm{~B}]$ shows that $6 \mathrm{~A} / 6 \mathrm{~A}$ allele was also found to be significant in subjects both over and under 45 years of age. While, $5 \mathrm{~A} / 5 \mathrm{~A}$ carrier alleles showed an association only in patients less than 45 years of age. Fisher's exact test also revealed that patients with $5 \mathrm{~A}$ alleles had a significant risk to develop OSMF ( $\mathrm{p}=0.01, \mathrm{OR}=2.51,95 \% \mathrm{CI}=1.27-4.94)$. [Table 3 and 4]. On the other hand, significant difference was found in MMP-3 genotype distribution (6A/6A, 5A/5A 


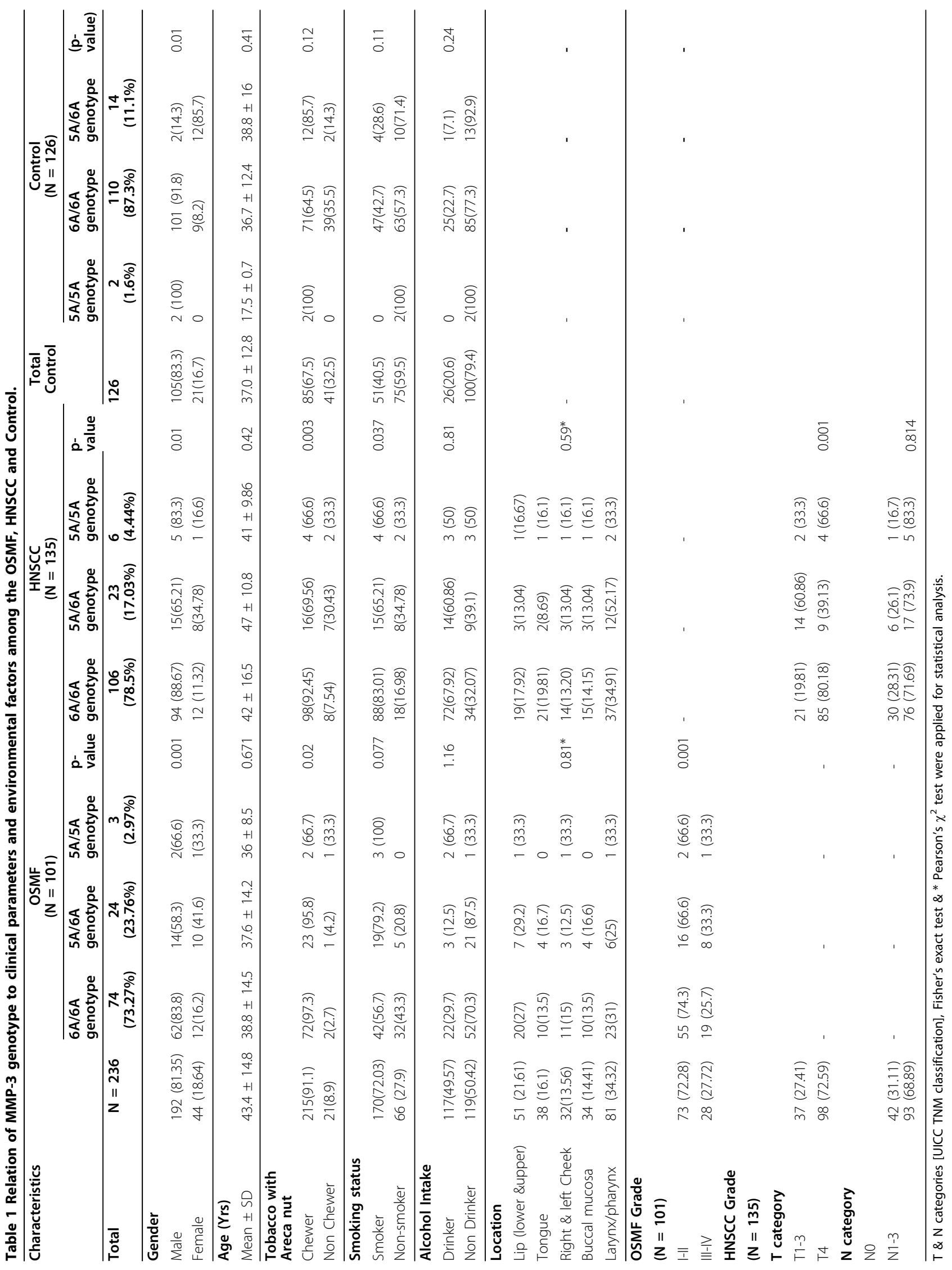


Table 2 The genotype and allele frequency of MMP-3 in OSMF, HNSCC patients and controls.

\begin{tabular}{lllllllll}
\hline Groups & $\begin{array}{l}\text { Total } \\
\mathbf{( N )}\end{array}$ & $\begin{array}{l}\mathbf{5 A} / \mathbf{5 A} \\
\text { Genotype }\end{array}$ & $\begin{array}{l}\mathbf{5 A} / \mathbf{6 A} \\
\text { Genotype }\end{array}$ & $\begin{array}{l}\mathbf{6 A} / \mathbf{6 A} \\
\text { Genotype }\end{array}$ & $\mathbf{5 A}$ allele frequency & $\mathbf{O R}$ & $\mathbf{9 5 \% C l}$ & $\mathbf{P}$-value \\
\hline Control & 126 & $2(1.58 \%)$ & $14(11.1 \%)$ & $110(87.3 \%)$ & 0.07 & 1 & - \\
\hline OSMF & 101 & $3(2.9 \%)$ & $24(23.7 \%)$ & $74(73.3 \%)$ & 0.15 & 2.26 & $1.22-4.20$ & 0.01 \\
\hline HNSCC & 135 & $6(4.44 \%)$ & $23(17.03 \%)$ & $106(78.52 \%)$ & 0.13 & 1.94 & $1.06-3.51$ & 0.03 \\
\hline
\end{tabular}

$\overline{[O R}=$ Odd Ratio; $\mathrm{Cl}=$ confidence interval; MMP = matrix metalloproteinase; OSMF = oral submucous fibrosis; HNSCC = Head and neck squamous cell carcinoma

and $5 \mathrm{~A} / 6 \mathrm{~A})$ between the areca nut with tobacco chewers and the non chewers both in $\operatorname{OSMF}(\mathrm{p}=0.02)$ and HNSCC ( $\mathrm{p}=0.003)$ patients vis-à-vis control group $(\mathrm{p}=$ 0.12 ) [Table 5 and 6 ]. However it should be noted that there are differences in age distribution, smoking and areca nut chewing between controls and patients.

\section{Discussion}

Carcinogenesis is a multistage process, which involves various molecular mechanisms associated to the fundamental alterations in cell physiology such as growth signals, escape from apoptosis, uncontrolled replication

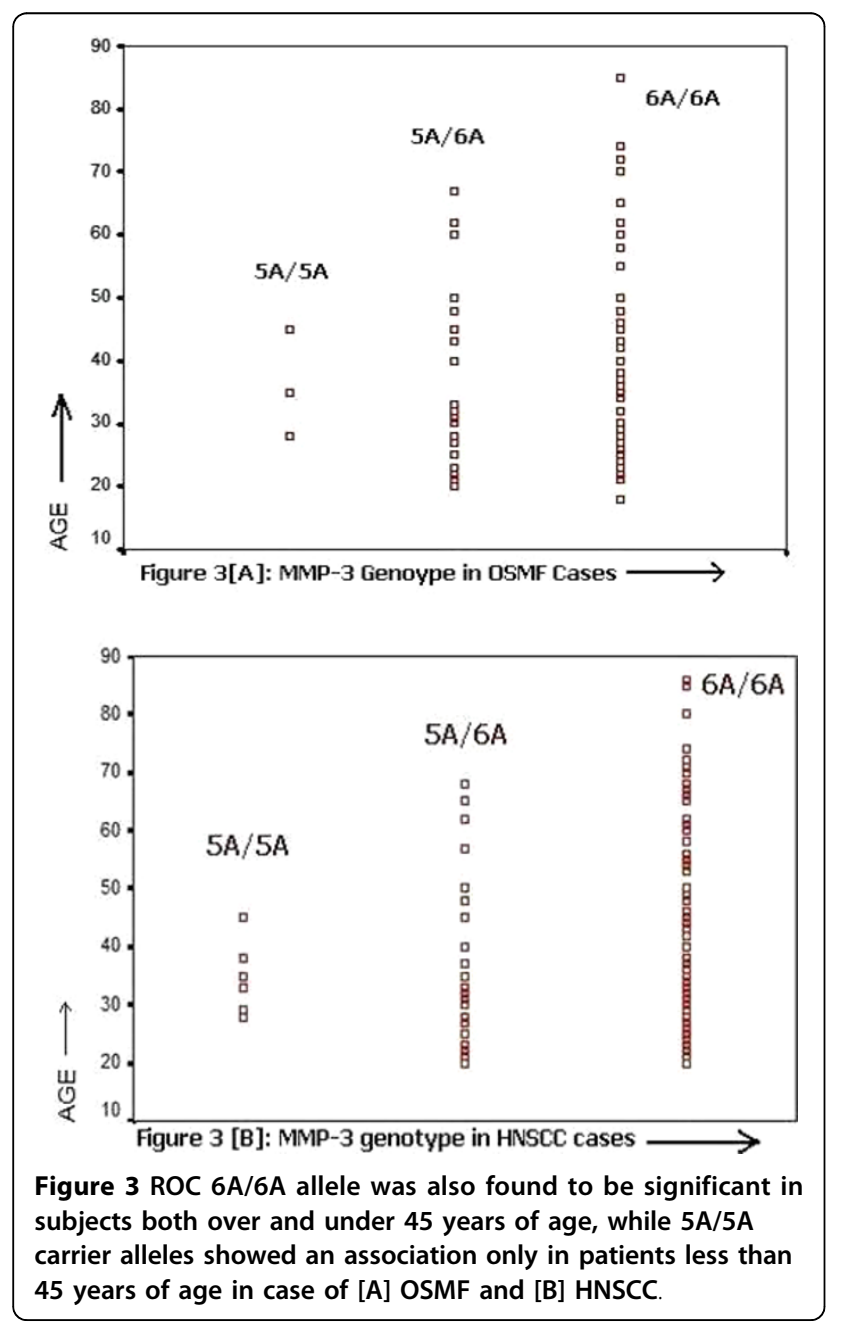

and growth-inhibitory signals [18]. MMPs are involved in the degradation of extra cellular matrix (ECM) components that take part in several molecular mechanisms such as invasion, angiogenesis, metastasis and progression of malignancies. Nagata et al suggested that expression levels of that molecules which are involved in tissue remodeling and cell-ECM adhesion, especially MMP-1 and integrin-3, may provide an accurate biomarker diagnosis for predicting the risk of cervical lymph node metastasis in oral squamous cell carcinoma (OSCC) [19]. Lin et al reported that functional promoter polymorphisms of MMP-1 and MMP-2 gene might be associated with the risk for development of OSCC but not in OSMF [20,21].

The MMP-3 promoter polymorphism is associated with a higher MMP-3 transcription level, Hashimoto et al reported that the MMP-3 SNP was not associated with the progression of OSCC as reflected by TNM and advances in stage [9]. In this study, a higher frequency of 5A allele was found in OSMF and HNSCC as compared to controls. This study supports the hypothesis that adenine insertion/deletion polymorphism in the MMP-3 promoter region was associated with the increased chance of development of OSMF. Tu et al also earlier reported the similar findings in OSMF patients from Taiwan [22].

Table 3 Univariate analysis of predictive factors in case of OSMF.

\begin{tabular}{|c|c|c|c|c|c|}
\hline & OSMF & CONTROL & p-value & OR & $95 \% \mathrm{Cl}$ \\
\hline \multicolumn{6}{|l|}{ Age } \\
\hline$<45$ & 76 & 64 & 0.001 & 2.94 & $1.66-5.21$ \\
\hline$\geq 45$ & 25 & 62 & & & \\
\hline \multicolumn{6}{|l|}{ Gender } \\
\hline Male & 77 & 105 & 0.24 & 0.64 & $0.33-1.23$ \\
\hline Female & 24 & 21 & & & \\
\hline \multicolumn{6}{|l|}{$6 A^{*}$} \\
\hline -ve & 3 & 2 & 0.79 & 1.89 & $0.05-6.93$ \\
\hline +ve & 98 & 124 & & & \\
\hline \multicolumn{6}{|l|}{$5 A^{* *}$} \\
\hline -ve & 74 & 110 & 0.01 & 2.508 & $1.27-4.94$ \\
\hline +ve & 27 & 16 & & & \\
\hline
\end{tabular}

${ }^{*} 6 \mathrm{~A}$-denotes $5 \mathrm{~A} / 5 \mathrm{~A}$ genotypes and $6 \mathrm{~A}$ +denotes $6 \mathrm{~A} / 6 \mathrm{~A}$ or $5 \mathrm{~A} / 6 \mathrm{~A}$. ${ }^{* *}$ : $5 \mathrm{~A}$ denotes $6 A / 6 A$ genotype and $5 A+$ denotes $5 A / 5 A$ or $5 A / 6 A$. Data were analyzed by Fisher's exact test. 
Table 4 Univariate analysis of predictive factors in case of HNSCC.

\begin{tabular}{|c|c|c|c|c|c|}
\hline & HNSCC & CONTROL & p-value & OR & $95 \% \mathrm{Cl}$ \\
\hline \multicolumn{6}{|l|}{ Age } \\
\hline$<45$ & 16 & 78 & 0.001 & 2.74 & $0.13-0.54$ \\
\hline$\geq 45$ & 36 & 48 & & & \\
\hline \multicolumn{6}{|l|}{ Gender } \\
\hline Male & 114 & 105 & 0.93 & 1.08 & $0.56-2.10$ \\
\hline Female & 21 & 21 & & & \\
\hline \multicolumn{6}{|l|}{$\overline{6 A^{*}}$} \\
\hline -ve & 6 & 2 & 0.03 & 2.93 & 0.58 .79 \\
\hline +ve & 129 & 126 & & & \\
\hline \multicolumn{6}{|l|}{$5 A^{* *}$} \\
\hline -ve & 106 & 110 & 0.02 & 1.8 & $0.96-3.66$ \\
\hline +ve & 29 & 16 & & & \\
\hline
\end{tabular}

* $6 \mathrm{~A}$-denotes $5 \mathrm{~A} / 5 \mathrm{~A}$ genotypes and $6 \mathrm{~A}+$ denotes $6 \mathrm{~A} / 6 \mathrm{~A}$ or $5 \mathrm{~A} / 6 \mathrm{~A}$. **: $5 \mathrm{~A}$ denotes $6 A / 6 A$ genotype and $5 A+$ denotes $5 A / 5 A$ or $5 A / 6 A$. Data were analyzed by Fisher's exact test.

MMPs play an important role in fibrosis of the oral cavity. OSMF is a premalignant disorder, which can be induced by areca nut chewing [23]. Due to excess chewing of areca nut; arecoline may increase the production of collagen fibers in the sub epidermal layer of buccal cavity and causes fibrosis. Chiu et al reported that areca chewing as well as polymorphism of genes associated with collagen homeostasis was correlated with risk of OSMF [24]. Shin et al suggested that polymorphism of transforming growth factor (TGF- $\alpha$ ) related to an innate immune response was also found to associated with the risk of OSMF [25]. In this study, a significant difference was found in MMP-3 genotype polymorphism between controls, OSMF and HNSCC patients.

Areca nut chewers having a $5 \mathrm{~A}$ allele had a higher risk for OSMF and HNSCC (OR $=2.26$ and 1.94 respectively) in relation to the control group. Tu et al reported a significant difference in MMP-3 genotypic polymorphism between patients with OSMF vis-à-vis controls in male areca chewers, however not in patients with OSCC from Taiwan [22]. On the other hand, Vairaktaris et al from Greece also reported a significant difference in the $5 \mathrm{~A}$ allele in oral cancer patients who smoked [26].

The presence of the $5 \mathrm{~A}$ allele has been reported to be associated with susceptibility for oral cancer, lung carcinoma, esophageal squamous cell carcinoma, head and neck carcinoma, ovarian cancer as well as breast carcinomas [22,27-31]. On the other hand, a patient with lower expression of $6 \mathrm{~A}$ allele has been associated with increased risk for colorectal cancer [32]. Nishijima et al reported that the anti-MMP-3 antibody is a serological marker that reflects the severity of systemic sclerosis and also suggested that it may contribute to the development of fibrosis by inhibiting MMP-3 activity and reducing the ECM [33]. Murawaki et al 1999 reported that measurement of serum MMP-3 is of little use for assessing fibrolysis in chronically diseased livers [34].

Tissue inhibitors of metalloproteinases (TIMPs) are the main endogenous inhibitors of the MMPs [35]. Strup-Perrot et al reported that expression of collagens; MMPs and TIMPs were increased simultaneously due to effect of collagen deposition in abdominal and pelvic cancers in radiation enteritis [36]. Chang et al found that arecoline acted not only as an inhibitor of gelatinolytic activity of MMP-2, but also a stimulator for TIMP1 activity in OSMF [37]. Their study concluded that MMPs transcription activity might be associated with genesis of OSMF in younger areca nut chewers.

In this study, 6A/6A alleles was found to be significant both in OSMF and HNSCC patients less than and more than 45 years of age, while $5 \mathrm{~A} / 5 \mathrm{~A}$ carrier alleles showed

Table 5 Age and habits distribution in relation to alleles in OSMF and Controls.

\begin{tabular}{|c|c|c|c|c|c|c|c|c|}
\hline \multirow[t]{2}{*}{ Characteristics } & \multicolumn{4}{|c|}{$\begin{array}{c}\text { OSMF } \\
(\mathrm{N}=101)\end{array}$} & \multicolumn{4}{|c|}{$\begin{array}{c}\text { Control } \\
(\mathrm{N}=126)\end{array}$} \\
\hline & $6 \mathrm{~A} / 6 \mathrm{~A}$ & $5 A / 6 A$ & $5 A / 5 A$ & p-value & $5 A / 5 A$ & $6 \mathrm{~A} / 6 \mathrm{~A}$ & $5 A / 6 A$ & (p-value) \\
\hline \multicolumn{9}{|l|}{ Age (Yrs) } \\
\hline Mean \pm SD & $38.8 \pm 14.5$ & $37.6 \pm 14.2$ & $36 \pm 8.5$ & 0.671 & $17.5 \pm 0.7$ & $36.7 \pm 12.4$ & $38.8 \pm 16$ & 0.41 \\
\hline \multicolumn{9}{|c|}{ Tobacco with Areca nut } \\
\hline Chewer & $72(97.3 \%)$ & $23(95.8 \%)$ & $2(66.7 \%)$ & 0.02 & $2(100 \%)$ & $71(64.5 \%)$ & $12(85.7 \%)$ & 0.12 \\
\hline Non Chewer & $2(2.7 \%)$ & $1(4.2 \%)$ & $1(33.3 \%)$ & & 0 & $39(35.5 \%)$ & $2(14.3 \%)$ & \\
\hline \multicolumn{9}{|l|}{ Smoking status } \\
\hline Smoker & $42(56.7 \%)$ & 19(79.2\%) & $3(100 \%)$ & 0.077 & 0 & $47(42.7 \%)$ & $4(28.6 \%)$ & 0.11 \\
\hline Non-smoker & $32(43.3 \%)$ & $5(20.8 \%)$ & 0 & & $2(100 \%)$ & $63(57.3 \%)$ & $10(71.4 \%)$ & \\
\hline \multicolumn{9}{|l|}{ Alcohol Intake } \\
\hline Drinker & $22(29.7 \%)$ & $3(12.5 \%)$ & $2(66.7 \%)$ & 1.16 & 0 & $25(22.7 \%)$ & $1(7.1 \%)$ & 0.24 \\
\hline Non Drinker & $52(70.3 \%)$ & $21(87.5 \%)$ & $1(33.3 \%)$ & & $2(100 \%)$ & $85(77.3 \%)$ & $13(92.9 \%)$ & \\
\hline
\end{tabular}

[Data was expressed as mean \pm SD and \%. Fischer exact test is used for habits in cases and control groups] 
Table 6 Age and habits distribution in relation to alleles in HNSCC and Controls

\begin{tabular}{|c|c|c|c|c|c|c|c|c|}
\hline \multirow[t]{2}{*}{ Characteristics } & \multicolumn{4}{|c|}{$\begin{array}{c}\text { HNSCC } \\
(N=135)\end{array}$} & \multicolumn{4}{|c|}{$\begin{array}{c}\text { Control } \\
(\mathrm{N}=126)\end{array}$} \\
\hline & $6 A / 6 A$ & $5 A / 6 A$ & $5 A / 5 A$ & $\mathrm{p}$-value & $5 A / 5 A$ & $6 A / 6 A$ & $5 A / 6 A$ & (p-value) \\
\hline \multicolumn{9}{|l|}{ Age (Yrs) } \\
\hline Mean \pm SD & $42 \pm 16.5$ & $47 \pm 10.8$ & $41 \pm 9.86$ & 0.42 & $17.5 \pm 0.7$ & $36.7 \pm 12.4$ & $38.8 \pm 16$ & 0.41 \\
\hline \multicolumn{9}{|c|}{ Tobacco with Areca nut } \\
\hline Chewer & $98(92.45 \%)$ & $16(69.56 \%)$ & $4(66.6 \%)$ & & $2(100 \%)$ & $71(64.5 \%)$ & 12(85.7\%) & 0.12 \\
\hline Non Chewer & $8(7.54 \%)$ & $7(30.43 \%)$ & $2(33.3 \%)$ & 0.003 & 0 & $39(35.5 \%)$ & $2(14.3 \%)$ & \\
\hline \multicolumn{9}{|l|}{ Smoking status } \\
\hline Smoker & $88(83.01 \%)$ & $15(65.21 \%)$ & $4(66.6 \%)$ & & 0 & $47(42.7 \%)$ & $4(28.6 \%)$ & 0.11 \\
\hline Non-smoker & 18(16.98\%) & $8(34.78 \%)$ & $2(33.3 \%)$ & 0.037 & $2(100 \%)$ & $63(57.3 \%)$ & 10(71.4\%) & \\
\hline \multicolumn{9}{|l|}{ Alcohol Intake } \\
\hline Drinker & $72(67.92 \%)$ & $14(60.86 \%)$ & $3(50 \%)$ & $0 . .81$ & 0 & $25(22.7 \%)$ & $1(7.1 \%)$ & 0.24 \\
\hline Non Drinker & $34(32.07 \%)$ & $9(39.1 \%)$ & $3(50 \%)$ & & $2(100 \%)$ & $85(77.3 \%)$ & $13(92.9 \%)$ & \\
\hline
\end{tabular}

[Data was expressed as mean \pm SD and \%. Fischer exact test is used for habits in HNSCC cases and control groups]

an association in OSMF and HNSCC patients less than 45 years of age. Nishizawa et al reported that apparent reduction of the MMP-1 1G/1G and 1G/2G genotypes distribution among the early onset OSCC cases under the ages of 45 years [38]. Since there were differences in age distribution, smoking and areca chewing between control and patients, the result need to be cautiously interpreted.

McCawley et al reported that high MMP-3 expression levels in OSCC may play an important role in oncogenesis and especially in invasion [39] Vairaktaris et al reported that the genotype containing $5 \mathrm{~A}$ allele had a two-fold risk of oral cancer development in smokers [26]. In this study, a significant difference was found in MMP-3 genotypic polymorphism between controls and HNSCC $(\mathrm{OR}=1.94)$, which is in concordance with results of Varkataris et al [26].

\section{Conclusions}

We conclude that adenosine insertion/deletion polymorphism (-1171 5A->6A) in the MMP-3 promoter region may play an important role in the development, initiation and progression of these lesions. To the best of our knowledge, this is the first study dealing with MMP-3 polymorphism in OSMF and HNSCC patients of Indian origin. Studies with a larger number of subjects are recommended to elucidate the genetic and polymorphic contribution of MMPs in these lesions, as this may have important role in designing future therapeutic strategies.

\section{Abbreviations}

(MMP): Matrix metalloproteinase; (ECM): Extra cellular Matrix; (SNP): single nucleotide polymorphism; (PCR): Polymerase chain reaction; (RFLP):

Restricion fragment length polymorphism; (OSMF): Oral submucous fibrosis; (HNSCC): head and neck squamous cell carcinoma; (OR): odds ratio; (95\% Cl): 95\% Confidence Intervals; (ROC): receiver operating characteristic curve.

\section{Acknowledgements}

The authors thank the University Grant Commission (UGC), New Delhi, for providing financial support (Grant No.32-188/2006-SR) to AKC (D. Phil Scholar) for this study. The authors wish to express their gratitude to Shruti Pandya, SRF \& D. Phil Scholar, in the Department of Pathology, MLN Medical College, University of Allahabad, for collection of the samples. Written consent was obtained for publication from the all patients or their relatives.

\section{Author details}

${ }^{1}$ Centre for Biotechnology, University of Allahabad, 211002 India. 2Department of Pathology, Moti Lal Nehru Medical College, Allahabad, 211002 India. ${ }^{3}$ Division of Molecular Oncology, Institute of Cytology and Preventive Oncology (ICPO), NOIDA, 201301, India. ${ }^{4}$ Department of Otolaryngology, Moti Lal Nehru Medical College, Allahabad, 211002 India. ${ }^{5}$ Department of Psychology, Allahabad Degree College, University of Allahabad, 211003 India.

\section{Authors' contributions}

AKC carried out the experimental work, analysis and drafted the manuscript. RM and Mamta Singh conceived of the study, participated in its design and coordination as well as helped to draft the manuscript. MS, ACB and SS participated in coordination of the study and helped to draft the manuscript. AKS participated in the statistical analysis. All authors read and approved the final manuscript.

\section{Competing interests}

The authors declare that they have no competing interests.

Received: 22 June 2009 Accepted: 14 July 2010 Published: 14 July 2010

\section{References}

1. Vihinen $P$, Kähäri VM: Matrix metalloproteinases in cancer: prognostic markers and therapeutic targets. Int J Cancer 2002, 99(2):157-66.

2. Matrisian LM: Cancer biology. Extracellular proteinases in malignancy. Curr Biol 1999, 9:776-778.

3. Impola U, Uitto VJ, Hietanen J, Hakkinen L, Zhang L, Larjava H, Isaka K, Saarialho-Kere U: Differential expression of matrilysin-1 (MMP-7), 92 kD gelatinase (MMP-9), and metalloelastase (MMP-12) in oral verrucous and squamous cell cancer. J Pathol 2004, 202(1):14-22.

4. Brinckerhoff $\mathrm{CE}$, Rutter JL, Benbow U: Interstitial collagenases as markers of tumor progression. Clin Cancer Res 2000, 6(12):4823-4830.

5. Johanssona N, Ahonenb M, Kähäri VM: Matrix metalloproteinases in tumor invasion. Cell Mol Life Sci 2000, 57:5-15.

6. Sage EH, Reed M, Funk SE, Truong T, Steadele M, Puolakkainen P, Maurice DH, Bassuk JA: Cleavage of the matricellular protein SPARC by matrix metalloproteinase 3 produces polypeptides that influence angiogenesis. J Biol Chem 2003, 278:37849-37857. 
7. Chaudhary AK, Singh M, Bharti AC, Asotra K, Sundaram S, Mehrotra R: Genetic polymorphisms of matrix metalloproteinases and their inhibitors in potentially malignant and malignant lesions of the head and neck. $J$ Biomed Sci 2010, 17:10.

8. Kahari VM, Saarialho-Kere U: Matrix metalloproteinases and their inhibitors in tumour growth and invasion. Ann Med 1999, 31:34-45.

9. Zinzindohouém F, Blons $H$, Hans S, Loriot MA, Houllier AM, Brasnu D, Laccourreye O, Tregouet DA, Stucker I, Laurent-Puig P: Single nucleotide polymorphisms in MMP1 and MMP3 gene promoters as risk factor in head and neck squamous cell carcinoma. Anticancer Res 2004, 24(3b):2021-6.

10. Hashimoto T, Uchida K, Okayama N, Imate $Y$, Suehiro $Y$, Hamanaka $Y$, Ueyama $Y$, Shinozaki F, Yamashita $H$, Hinoda $Y$ : Association of matrix metalloproteinase (MMP)-1 promoter polymorphism with head and neck squamous cell carcinoma. Cancer Lett 2004, 211(1):19-24.

11. Fang $S$, Jin $X$, Wang R, Li Y, Guo W, Wang N, Wang Y, Wen D, Wei L, Zhang J: Polymorphisms in the MMP1 and MMP3 promoter and nonsmall cell lung carcinoma in North China. Carcinogenesis 2005, 26:481-486.

12. Ghilardi G, Biondi ML, Caputo M, Leviti S, DeMonti M, Guagnellini E, Scorza R: A single nucleotide polymorphism in the matrix metalloproteinase-3 promoter enhances breast cancer susceptibility. Clin Cancer Res 2002, 8(12):3820-3823.

13. Ashworth $J$, Murphy $G$, Rock MJ: Fibrillin degradation by matrix metalo protienase: Implication for connective tissue remodelling. Biochem J 1999, 340(Pt 1):171-81

14. Ye S, Eriksson P, Hamsten A, Kurkinen M, Humphries SE, Henney AM: Progression of coronary atherosclerosis is associated with a common genetic variant of the human stromelysin-1 promoter which results in reduced gene expression. J Biol Chem 1996, 271(22):13055-13060.

15. Ye S, Watts GF, Mandalia S, Humphries SE, Henney AM: Preliminary report; genetic variation in the human stromelysin promoter is associated with progression of coronary atherosclerosis. Br Heart J 1995, 73:209-15.

16. Su L, Zhou W, Asomaning K, Lin X, Wain JC, Lynch TJ, Liu G, Christiani DC: Genotypes and haplotypes of matrix metalloproteinase 1, 3 and 12 genes and the risk of lung cancer. Carcinogenesis 2006, 27:1024-1029.

17. Gnasso A, Motti C, Irace C, Carallo C, Liberatoscioli L, Bernardini S, Massoud R, Mattioli PL, Federici G: Genetic variation in human stromelysin gene promoter and common carotid geometry in healthy male subjects. Arterioscler Thromb Vasc Biol 2000, 20:1600-1605.

18. Hanahan D, Weinberg RA: The hallmarks of cancer. Cell 2003, 100:57-70.

19. Nagata M, Fujita $H$, Ida H, Hoshina $H$, Inoue $T$, Seki $Y$, Ohnishi M, Ohyama T, Shingaki S, Kaji M: Identification of potential biomarkers of lymph node metastasis in oral squamous cell carcinoma by cDNA microarray analysis. Int J Cancer 2003, 106(5):683-689.

20. Lin SC, Lo SS, Liu CJ, Chung MY, Huang JW, Chang KW: Functional genotype in matrix metalloproteinases-2 promoter is a risk factor for oral carcinogenesis. J Oral Pathol Med 2004, 33:405-9.

21. Lin SC, Chung MY, Huang JW, Shieh TM, Liu CJ, Chang KW: Correlation between functional genotypes in the matrix metalloproteinasespromoter and risk of oral squamous cell carcinomas. J Oral Pathol Med 2004, 33:323-6.

22. Tu HF, Liu CJ, Chang CS, Lui MT, Kao SY, Chang CP, Liu TY: The functional $-1171(5 \mathrm{~A} / 6 \mathrm{~A})$ polymorphisms of matrix metalloproteinase 3 gene as a risk factor for oral submucous fibrosis among male areca users. Oral Pathol Med 2006, 3(5):99-103.

23. Pandya S, Chaudhary AK, Sngh M, Mehrotra R: Correlation of histopathological diagnosis with habits and clinical findings in oral submucous fibrosis. Head \& neck Oncology 2009, 1(1):11

24. Chiu CJ, Chiang CP, Chang ML: Association between genetic polymorphism of tumour necrosis factor-alpha and risk of oral submucous fibrosis, a pre cancerous condition of oral cancer. J Dent Res 2001, 80(12):2055-2059.

25. Shin YN, Lin CJ, Chang KW, Lee YJ, Liu HF: Association of CTLA-4 gene polymorphism with oral submucous fibrosis in Taiwan. $J$ Oral Pathol Med 2004, 33:200-3.

26. Vairaktaris E, Yapijakis C, Vasiliou S, Derka S, Nkenke E, Serefoglou Z, Vorris E: Association of -1171 promoter polymorphism of matrix metalloproteinase-3 with increase risk for oral cancer. Anticancer Res 2007, 27(6B):4095-100.
27. Fang $S$, Jin $X$, Wang R, Li Y, Guo W, Wang N, Wang Y, Wen D, Wei L, Zhang J: Polymorphisms in the MMP1 and MMP3 promoter and nonsmall cell lung carcinoma in North China. Carcinogenesis 2005, 26:481-486.

28. Zhang J, Jin X, Fang S, Li Y, Wang R, Guo W, Wang N, Wang Y, Wen D, Wei $L$, Kuang $G$, Dong $Z$ : The functional SNP in the matrix metalloproteinase-3 promoter modifies susceptibility and lymphatic metastasis in esophageal squamous cell carcinoma but not in gastric cardiac adenocarcinoma. Carcinogenesis 2004, 25:2519-2524.

29. Blons $\mathrm{H}$, Gad S, Zinzindohoué F, Manière I, Beauregard J, Tregouet D, Brasnu D, Beaune P, Laccourreye $O$, Laurent-Puig P: Matrix metalloproteinase 3 polymorphism: a predictive factor of response to neoadjuvant chemotherapy in head and neck squamous cell carcinoma. Clin Cancer Res 2004, 10(8):2594-9.

30. Smolarz B, Szyłło K, Romanowicz-Makowska H, Niewiadomski M, Kozłowska E, Kulig A: PCR analysis of matrix metalloproteinase 3 (MMP-3) gene promoter polymorphism in ovarian cancer. Pol J Pathol 2003, 54(4):233-8.

31. Yoon S, Tromb G, Vongpunsawad S, Ronkainen A, Juvonen T, Kuivaniemi H: Genetic analysis of MMP3 and MMP9 and PAI-1 in Finnish patients with abdominal aortic or intracranial aneurysms. Biochem Biophys Res Communic 1999, 265:563-568.

32. Hinoda Y, Okayama N, Takano N, Fujimura K, Suehiro Y, Hamanaka Y, Hazama S, Kitamura Y, Kamatani N, Oka M: Association of functional polymorphisms of matrix metalloproteinase-1 (MMP-1) and MMP-3 genes with colorectal cancer. Int J Cancer 2002, 102:526-529.

33. Nishijima C, Hayakawa I, Matsushita T, Komura K, Hasegawa M, Takehara K, Sato S: Autoantibody against matrix metalloproteinase-3 in patients with systemic sclerosis. Clin Exp Immunol 2004, 138(2):357-63.

34. Murawaki $Y$, Ikuta $Y$, Idobe $Y$, Kawasaki H: Serum matrixmetalloproteinase1 in patients with chronic viral hepatitis. J Gastroenterol Hepatol 1999, 14(2):138-45.

35. Visse $R$, Nagase $H$ : Matrix metalloproteinases and tissue inhibitors of metalloproteinases: structure, function and biochemistry. Circ Res 2003, 92:827-839.

36. Strup-Perrot C, Mathé D, Linard C, Violot D, Milliat F, François A, Bourhis J, Vozenin-Brotons MC: Global gene expression profiles reveal an increase in mRNA levels of collagens, MMPs, and TIMPs in late radiation enteritis. Am J Physiol Gastrointest Liver Physiol 2004, 287(4):G875-85.

37. Chang YC, Yang SF, Tai KW, Chou MY, Hsieh S: Increased tissue inhibitor of metalloproteinase- 1 expression and inhibition of gelatinase: A activity in buccal mucosal fibroblasts by arecoline as possible mechanisms for oral submucous fibrosis. Oral Oncol 2002, 38(2):195-200.

38. Nishizawa $R$, Nagata M, Noman AA, Kitamura N, Fujita $H$, Hoshina $H_{\text {, }}$ Kubota T, Itagaki M, Shingaki S, Ohnishi M, Kurita H, Katsura K, Saito C, Yoshie $\mathrm{H}$, Takagi $\mathrm{R}$ : The $2 \mathrm{G}$ allele of promoter region of matrix metalloproteinase-1 as an essential pre-condition for the early onset of oral squamous cell carcinoma. BMC Cancer 2007, 7:187.

39. McCawley L, Crawford H, King L, Mudgett J, Matrisian L: Aprotective role for matrix metalloproteinase-3 in squamous cell carcinoma. Cancer Res 2004, 64:6965-6972.

\section{Pre-publication history}

The pre-publication history for this paper can be accessed here: http://www.biomedcentral.com/1471-2407/10/369/prepub

\section{doi:10.1186/1471-2407-10-369}

Cite this article as: Chaudhary et al:: Synergistic effect of stromelysin-1 (matrix metalloproteinase-3) promoter (-1171 5A->6A) polymorphism in oral submucous fibrosis and head and neck lesions. BMC Cancer 2010 10:369. 